DOI: 10.15393/j10.art.2019.4022

УДК 930.25

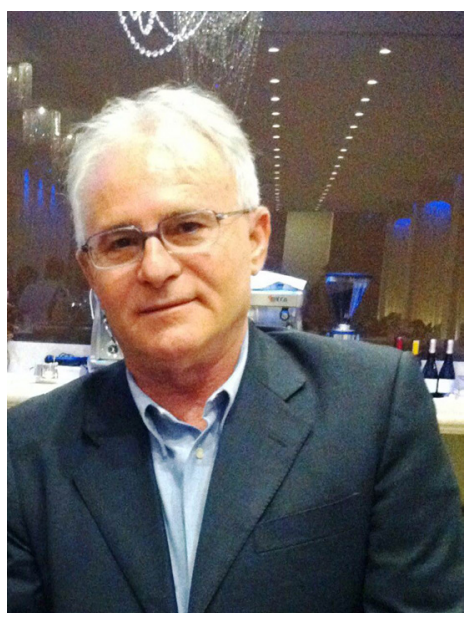

Джузеппе Астуто

(Катания, Италия) astuto@unict.it

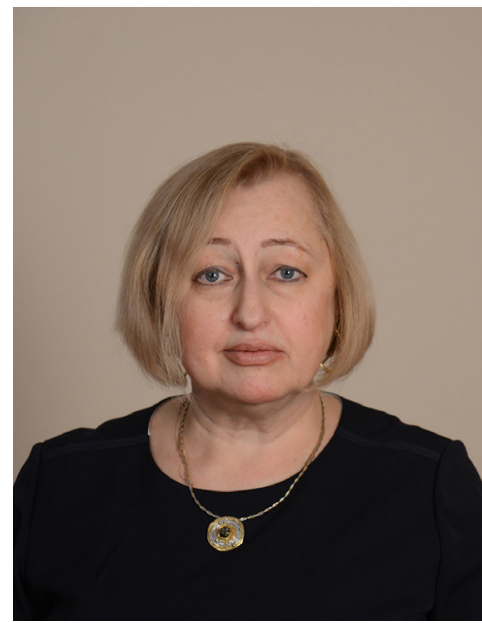

Ирина Владимировна Дергачева

(Москва, Российская Федерация) krugh@yandex.ru

\title{
По следам Ф. М. Достоевского во Флоренции
}

Аннотация. В статье представлены результаты архивного поиска следов пребывания Достоевского во Флоренции, проведенного весной 2019 г. Найдены и проанализированы новые документы, дополняющие историю судебного исполнительного листа лужского купца Бурковского, так и не врученного писателю по причине его отъезда из города. В Государственном архиве Флоренции были обнаружены два документа, составленные по указанию префекта в ответ на ноту временного поверенного г. Глинки и содержащие просьбу о розыске писателя для вручения ему вышеупомянутого документа. Впервые приводится также фотокопия записи из приходского экземпляра метрической книги 1868 г., хранящейся в православном храме Рождества Христова и Святителя Николая, о смерти, отпевании и захоронении С. П. Колошина, журналиста и корреспондента Достоевского, чей архив, возможно включающий письма Достоевского, до сих пор не найден.

Ключевые слова: Достоевский, С. П. Колошин, Флоренция, православный храм Рождества Христова и Святителя Николая, метрические книги, судебный розыск, Государственный архив Флоренции, Исторический архив Флоренции

Об авторах: Acmymо Джузеппе - $\mathrm{PhD}$, профессор истории политических учреждений при факультете политических наук, университет Катании (95131, Италия, Катания CT, Via Vittorio Emanuele II, 49); Дергачева Ирина Владимировна - доктор филологических наук, профессор, зав. кафедрой лингвистики факультета Государственной культурной политики, Московский государственный институт культуры (141 406, Российская Федерация, Московская обл., г. Химки, ул. Библиотечная, 7)

Дата поступления: 20.05.2019

Дата публикации: 30.06.2019

Для цитирования: Астуто Дж., Дергачева И. В. По следам Ф. М. Достоевского во Флоренции // Неизвестный Достоевский. - 2019. - № 2. - C. 130-148. DOI: 10.15393/j10. art.2019.4022 
$\Phi$ едор Михайлович Достоевский побывал во Флоренции дважды. В 1862 г. вместе с Н. Н. Страховым он провел здесь около 10 дней (с 3 по 12 августа). О первом знакомстве в 1862 г. со столицей королевства Италии писатель вспоминал с ностальгией в письме критику от 12 (24) декабря 1868 г.:

«Теперь сижу во Флоренции уже недели с две, и, кажется, долго придется просидеть, всю зиму, по крайней мере, и часть весны. А помните, как мы с Вами сиживали по вечерам, за бутылками, во Флоренции (причем Вы были каждый раз запасливее меня: Вы приготовляли себе 2 бутылки на вечер, а я только одну, и, выпив свою, добирался до Вашей, чем, конечно, не хвалюсь)? Но все-таки те 5 дней во Флоренции мы провели недурно. Теперь Флоренция несколько шумнее и пестрее, давка на улицах страшная. Много народу привалило как в столицу; жить гораздо дороже, чем прежде, но сравнительно с Петербургом все-таки сильно дешевле»1.

В 1869 г. Достоевский вместе с женой Анной Григорьевной находился во Флоренции восемь месяцев. Этот город стал для него самым значимым в четырехлетнем вынужденном пребывании за рубежом. Здесь писатель закончил работу над романом «Идиот». Флорентийская атмосфера действовала на писателя благотворно - несмотря на то, что он был вынужден «затвориться», чтобы писать, супруги находили время для посещения достопримечательностей города, которые вызывали восхищение Достоевского:

«...В конце ноября 1868 года мы перебрались в тогдашнюю столицу Италии и поселились вблизи Palazzo Pitti. Перемена места опять повлияла благоприятно на моего мужа, и мы стали вместе осматривать церкви, музеи и дворцы. Помню, как Федор Михайлович приходил в восхищение от Cattedrale, церкви Santa Maria del fiore и от небольшой капеллы del Battistero, в которой обычно крестят младенцев. Бронзовые двери Battistero (особенно detta del Paradiso), работы знаменитого Ghiberti, очаровали Федора Михайловича, и он, часто проходя мимо капеллы, всегда останавливался и рассматривал их. Муж уверял меня, что если ему случится разбогатеть, то он непременно купит фотографии этих дверей, если возможно в натуральную их величину, и повесит у себя в кабинете, чтобы на них любоваться.

Часто мы с мужем бывали в Palazzo Pitti, и он приходил в восторг от картины Рафаэля “Madonna della Sedia”. Другая картина того же художника “S. Giovan Battista nel deserto" (“Иоанн Креститель в пустыне”), находящаяся в галереe Uffizi, тоже приводила в восхищение Федора Михайловича, и он всегда долго стоял перед нею. Посетив картинную галерею, он непременно шел смотреть в том же здании статую Venere de Medici (Венеру Медицийскую), работы знаменитого греческого скульптора Клеомена. Эту статую мой муж признавал гениальным произведением» [Достоевская: 236].

Genius loci Флоренции постоянно присутствует в текстах Достоевского. Так, в «Дневнике писателя» за май — июнь 1877 г. он развивает мысль 
о великом предназначении Италии как страны, призванной объединить человечество на основе идеального образа красоты:

«...2500 лет носила в себе Италия мировую и объединяющую мир идею не отвлеченную какую-нибудь, не спекуляцию кабинетного ума, а реальную, органическую, плод жизни нации, плод мировой жизни: это было объединение всего мира - сначала древнеримское, потом папское. Народы, взраставшие и преходившие в эти два с половиной тысячелетия в Италии, понимали, что они носители мировой идеи, а непонимавшие чувствовали и предчувствовали это. Наука, искусство - всё облекалось и проникалось этим же мировым значением» (Д30; 25: 143).

Пребывание Ф. М. Достоевского во Флоренции неоднократно привлекало внимание исследователей ${ }^{2}$. С. Алоэ писал о пребывании писателя в итальянских городах и о рецепции его художественного наследия в Италии; А. А. Кара-Мурза обобщил данные о пребывании Достоевского во Флоренции, приведенные в исследованиях бельгийского ученого Гедройца и итальянских ученых Л. Тонини и В. Супино; М. Г. Талалай описал историю русского храма во Флоренции и российского некрополя в Италии. В. Н. Захаров опубликовал переписку 1864-1865 гг. Достоевского и журналиста Сергея Колошина, проживавшего в Италии [Захаров, 2013], а также архивные материалы по поводу судебного розыска писателя во Флоренции в 1871 г. [3ахаров, 2012]. Наши архивные поиски продолжили исследования, проведенные В. Н. Захаровым. Их результатом стало обнаружение новых сведений о судебном розыске писателя и точных свидетельств о дате смерти и месте захоронения С. П. Колошина.

По записи Ф. М. Достоевского в читальном зале научного и литературного кабинета Дж. П. Вьёссё член Международного общества Достоевского А. Н. Гедройц (Брюссель) в 1974 г. установил адрес, по которому писатель проживал во Флоренции во время своего первого пребывания там. Перевод этой записи опубликован в 4-м томе издания «Достоевский. Материалы и исследования» (Л., 1980) в статье «Достоевский - абонент флорентийской читальни»: «Федор Достоевский. Заплачено за неделю. Адрес: Швейцарская гостиница. № 20». В записи также зафиксирована дата абонемента писателя и Н. Н. Страхова во Флоренции в 1862 г.: «с 15-16 по 21-22 августа (т. е. с 3-4 по 9-10 августа ст. стиля» [Достоевский - абонент: 175].

А. А. Кара-Мурза указал, что в современное время пансион «Швейцария» был переименован в отель «Алберготто»:

«Ф. М. Достоевский первый раз приехал во Флоренцию летом 1862 г. вместе с литератором Николаем Николаевичем Страховым. Они остановились тогда в пансионе “Швейцария" на углу улиц Торнабуони и Винья-Нуова (прямо напротив Палаццо Строцци) в комнате № 20 на третьем этаже. Пансион “Швейцария” (сегодня здесь находится скромный “Hotel Albergotto") 
известен тем, что здесь останавливались многие знаменитые иностранцы; в частности, незадолго до Достоевского и Страхова здесь проживала Дж. Элиот» [Кара-Мурза: 205].

Согласно записи, хранящейся в «Кабинете Вьёссё», Ф. М. Достоевский и Н. Н. Страхов жили в пансионе на 3-м этаже в 20-м номере. К сожалению, до нашего времени их номер в первозданном виде не сохранился. Отель «Albergotto», располагавшийся по адресу: via Tornabuoni, 1350123 Firenze, реконструирован новым владельцем испанского происхождения и переименован в «Isabella». Какое-либо указание на проживание здесь знаменитого русского писателя на доме отсутствует (см.: Илл. 1-2).

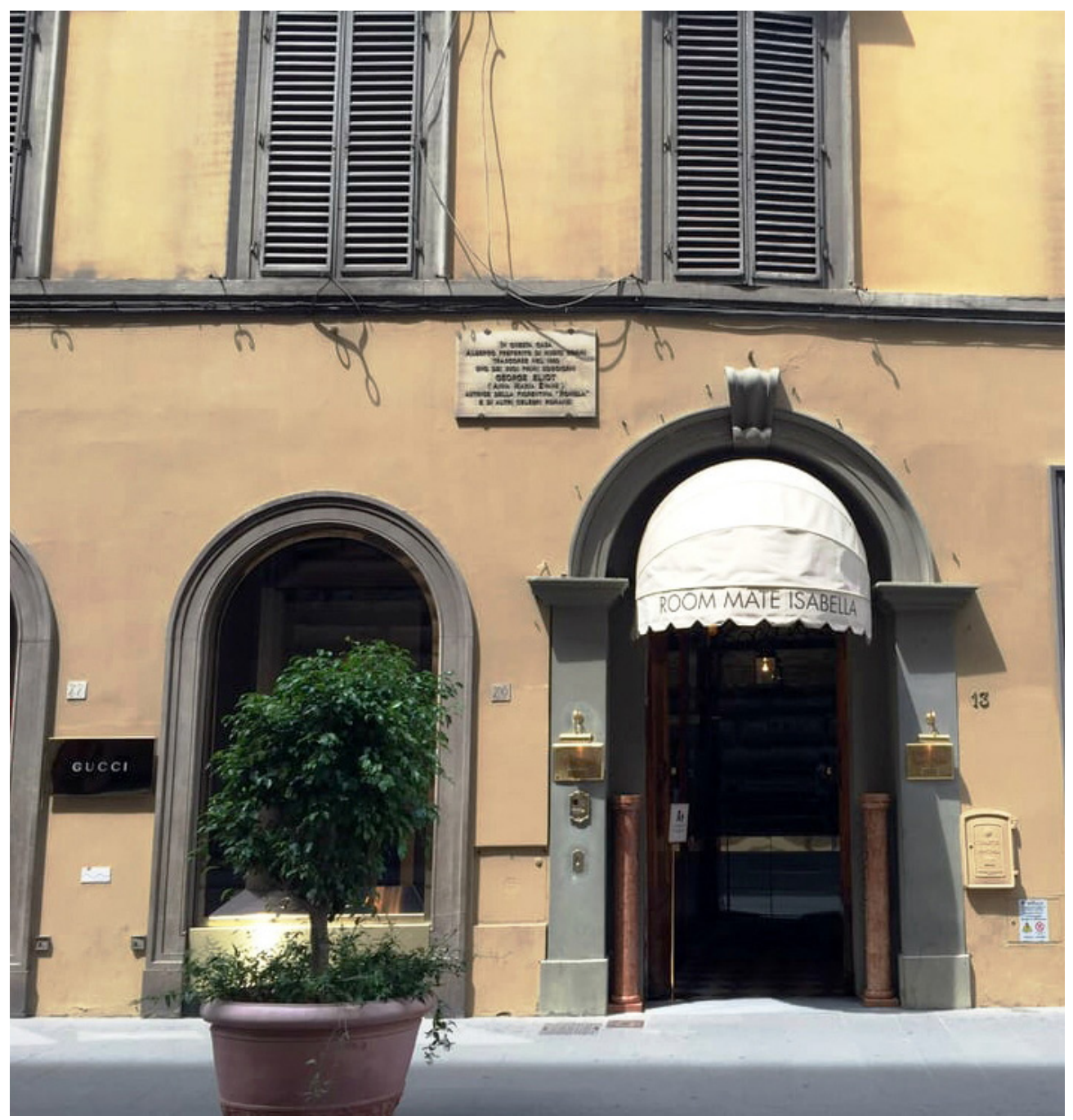

Илл. 1. Отель «Isabella», Флоренция. Общий вид ${ }^{3}$ 


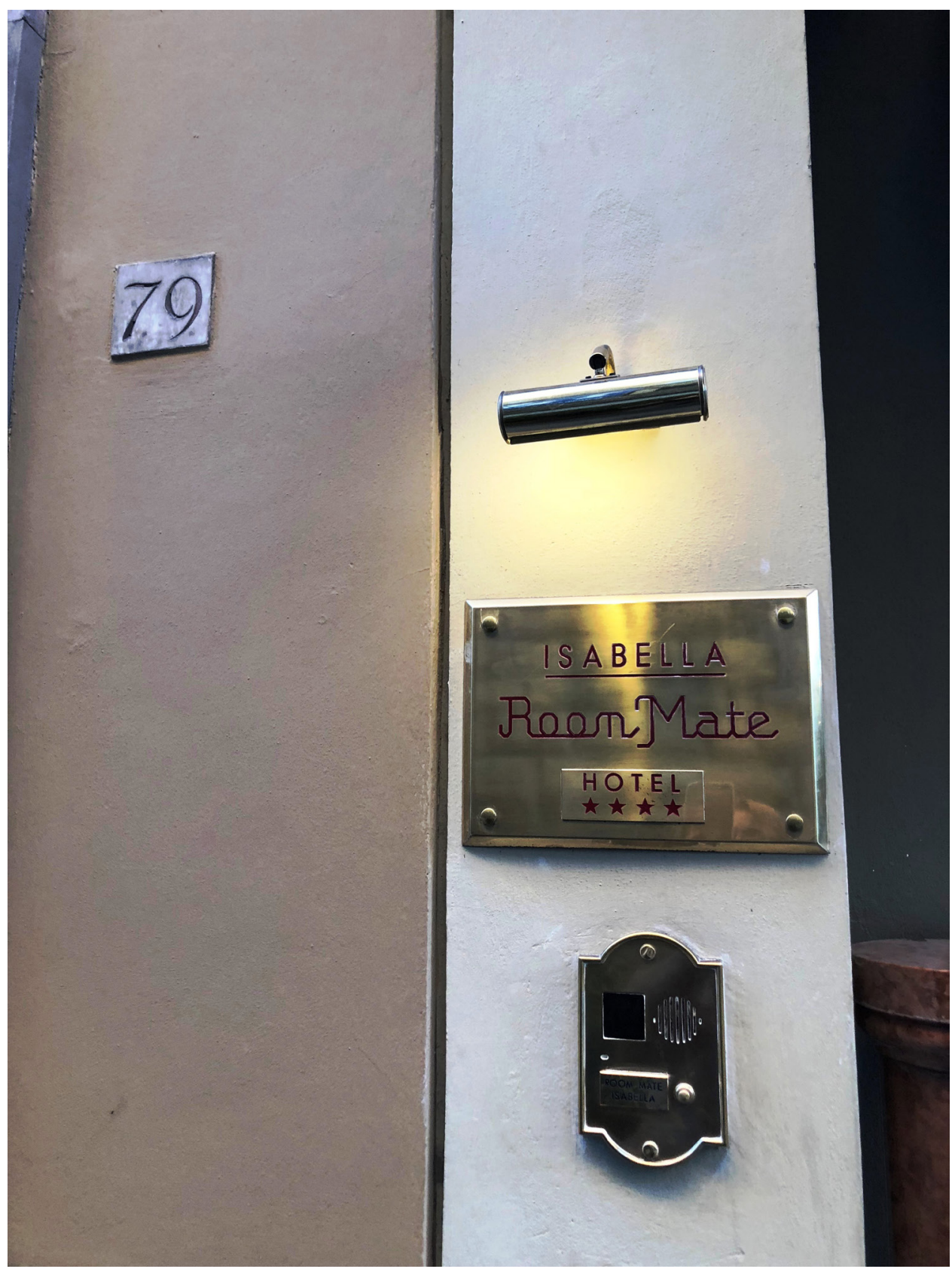

Илл. 2. Отель «Isabella», Флоренция

Второе пребывание Ф. М. Достоевского во Флоренции было достаточно длительным - около восьми месяцев. Флорентийские адреса проживания супругов Достоевских уточнила итальянская исследовательница Валентина Супино. В своей работе она также опиралась на сведения, сохранившиеся 
в «Кабинете Вьёссё». В абонементе читальни значились два адреса: улица Гвиччардини и Меркато дель Порчеллино. О первом адресе на улице Гвиччардини (via Guiccirdini) она пишет: «Если считать от начала моста Ponte Vecchio на углу с ул. Борго Сан Якопо (Borgo S. Jасоро), дом № 8, где поселился Федор Михайлович, был четвертым домом справа, так как, находясь за р. Арно, дома с четными номерами расположены справа от ул. Гвиччардини, а с нечетными - слева. <...> Старые довоенные карты свидетельствуют о том, что дома №№ 8, 10, 12 и 14 выходили на площадь Санта-Феличита. Ныне здание полностью отреставрировано, и из окон помещения, которое первоначально располагалось на третьем этаже, открывается вид на площадь с церковью Санта-Феличита и частью сада Боболи (Giardino Boboli)...» [Cyпино: 12]. Окна второго жилья выходили на рынок Порчеллино. Этот дом сохранился до наших дней под тем же № 1, что и во времена Достоевского. «Так, - продолжает исследовательница, - в письме из Флоренции Аполлону Майкову от 15 (27) мая Достоевский жалуется, что из-за нехватки средств вынужден жить с женой и тещей "в теснейшей маленькой комнатке, выходящей на рынок” (Д30, 29, 43). Этим рынком был Меркато дель Порчеллино (Mercato del Porcellino), что следует из уже упомянутого письма писателя С. А. Ивановой от 29 августа (10 сентября) 1869 г. Там, пишет Достоевский, они жили с мая и до самого отъезда из Флоренции 3 августа 1869 г.» [Супино: 17].

Документы о Ф. М. Достоевском и его корреспонденте С. П. Колошине в ходе поисков весной 2019 г. в Историческом архиве коммуны Флоренции (Archivio Storico Comunale di Firenze) и в Государственном архиве Флоренции (Archivio di Stato di Firenze) обнаружены не были. Изучение фондов квестуры (Questura di Firenze) и префектуры (Prefettura di Firenze) на предмет наличия в них соответствующих документов также дало отрицательный результат - вероятно, потому, что в данных фондах имеются лакуны. Так, например, в Государственный архив не попали документы из Кабинетов (Gabinetti) данных учреждений. Кроме того, в 1930-е гг. прошло сокращение архива, в результате которого при нем сохранились лишь отдельные папки, именующиеся «Документы полиции» (Carte di Polizia), которые содержат деловые бумаги, касающиеся полицейского контроля за анархическими и социалистическими организациями. Другой проблемой является отсутствие описей - для получения нужной информации необходимо изучить десятки объемных папок. Так, фонд «Приказы» (Affari ordinari) префектуры содержит раздел «Гражданская безопасность» (Sicurezza Pubblica). В ней располагаются в том числе и сведения о местонахождении иностранцев, которые могли вызвать внимание полиции. Архив не располагает адресными книгами (Rubriche) периода пребывания Достоевского и Колошина в Италии - первая из них относится уже к 1882 г. Исследование документов, содержащихся в папках «Общего протокола» ("Protocollo Generale”), проведенное в фондах квестуры (“Questura”), показало, что в них отсутствуют какие-либо сведения о возможном негласном наблюдении за Достоевским или Колошиным. 
Однако в фондах квестуры были обнаружены два документа, составленные по указанию префекта в ответ на ноту временного поверенного г. Д. Г. Глинки с просьбой о розыске Достоевского для вручения ему исполнительного листа. В фондах квестуры Флоренции (Fondi di Questura di Firenze e Prefettura (rappresentanza del territorio di autorita' statale) в каталоге разделов общих протоколов квестуры (Le Rubriche di protocollo generale della Questura) под № 12757 была обнаружена следующая запись (см.: Илл. 3):

\begin{tabular}{|c|c|c|c|}
\hline $\begin{array}{c}\text { NUMERO } \\
\text { del } \\
\text { PROTOCOLLO }\end{array}$ & OGGETTO & $\begin{array}{c}\text { dell' } \\
\text { AFFARE }\end{array}$ & $\begin{array}{c}\text { NUMERO } \\
\text { della } \\
\text { CATEGORIA }\end{array}$ \\
\hline 12757 & $\begin{array}{c}\text { Dostoewsky Teodoro } \\
\text { consegna-piego }\end{array}$ & 51 & 19 \\
\hline Номер протокола & Предмет & Дело & Номер единицы хранения \\
\hline 12757 & $\begin{array}{c}\text { Достоевский Феодор } \\
\text { доставка исполнительного } \\
\text { листа }\end{array}$ & 51 & 19 \\
\hline
\end{tabular}

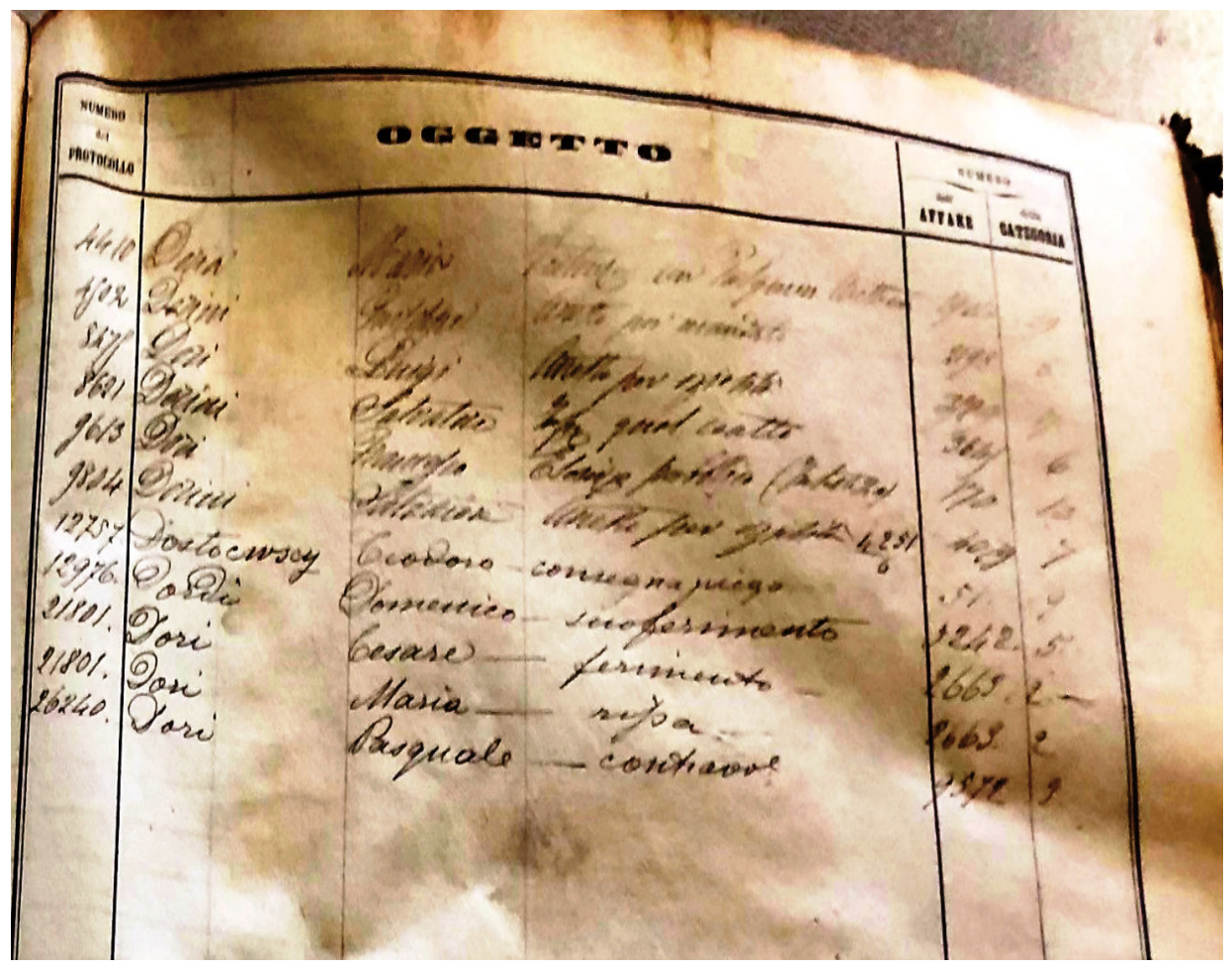

Илл. 3. Запись о доставке исполнительного листа.

(Фонд квестуры Флоренции. Д. 51. Ед. хр. 19) 
В общих протоколах квестуры под № 51, ед. хр. 19 находится более подробная информация об этом исполнительном листе (см.: Илл. 4):

\begin{tabular}{|c|c|c|c|c|c|c|c|c|}
\hline 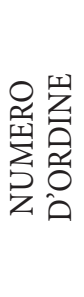 & 岕龸芯 & 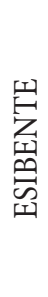 & 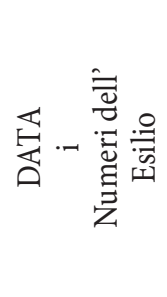 & 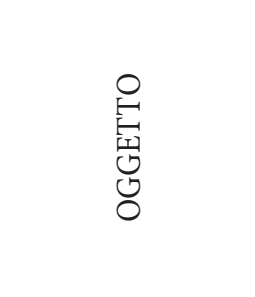 & 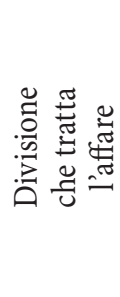 & 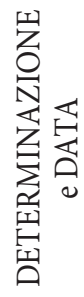 & 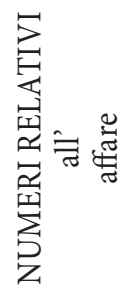 & 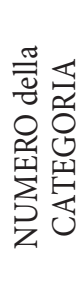 \\
\hline $\begin{array}{l}\stackrel{N}{\Lambda} \\
\end{array}$ & .] & 苋 & ஏ & $\begin{array}{c}\text { Prega per } \\
\text { consegnare pie go } \\
\text { al sig. Teodoro } \\
\text { Dostoewscy da } \\
\text { parte } \\
\text { della Legazione } \\
\text { Russa. }\end{array}$ & $m$ & 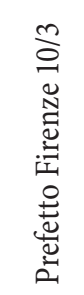 & $\bar{n}$ & 9 \\
\hline \multicolumn{9}{|c|}{ Перевод } \\
\hline 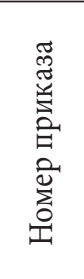 & 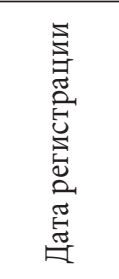 & 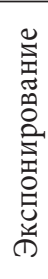 & 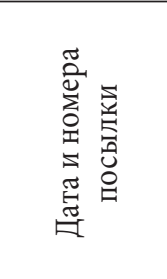 & Объект & 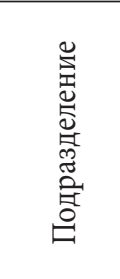 & 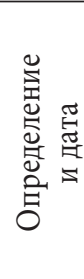 & 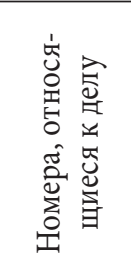 & 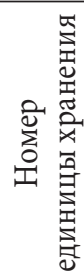 \\
\hline 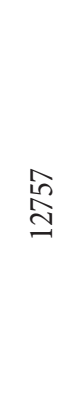 & 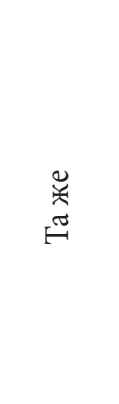 & $\begin{array}{l}\ddot{x} \\
0 \\
0\end{array}$ & 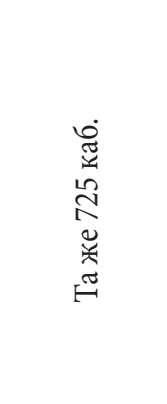 & $\begin{array}{c}\text { Просьба вручить } \\
\text { исполни- } \\
\text { тельный лист } \\
\text { господину } \\
\text { Феодору Достоев- } \\
\text { скому со стороны } \\
\text { Российского } \\
\text { Представи- } \\
\text { тельства }\end{array}$ & $m$ & 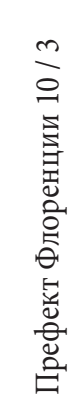 & $\vec{n}$ & 9 \\
\hline
\end{tabular}




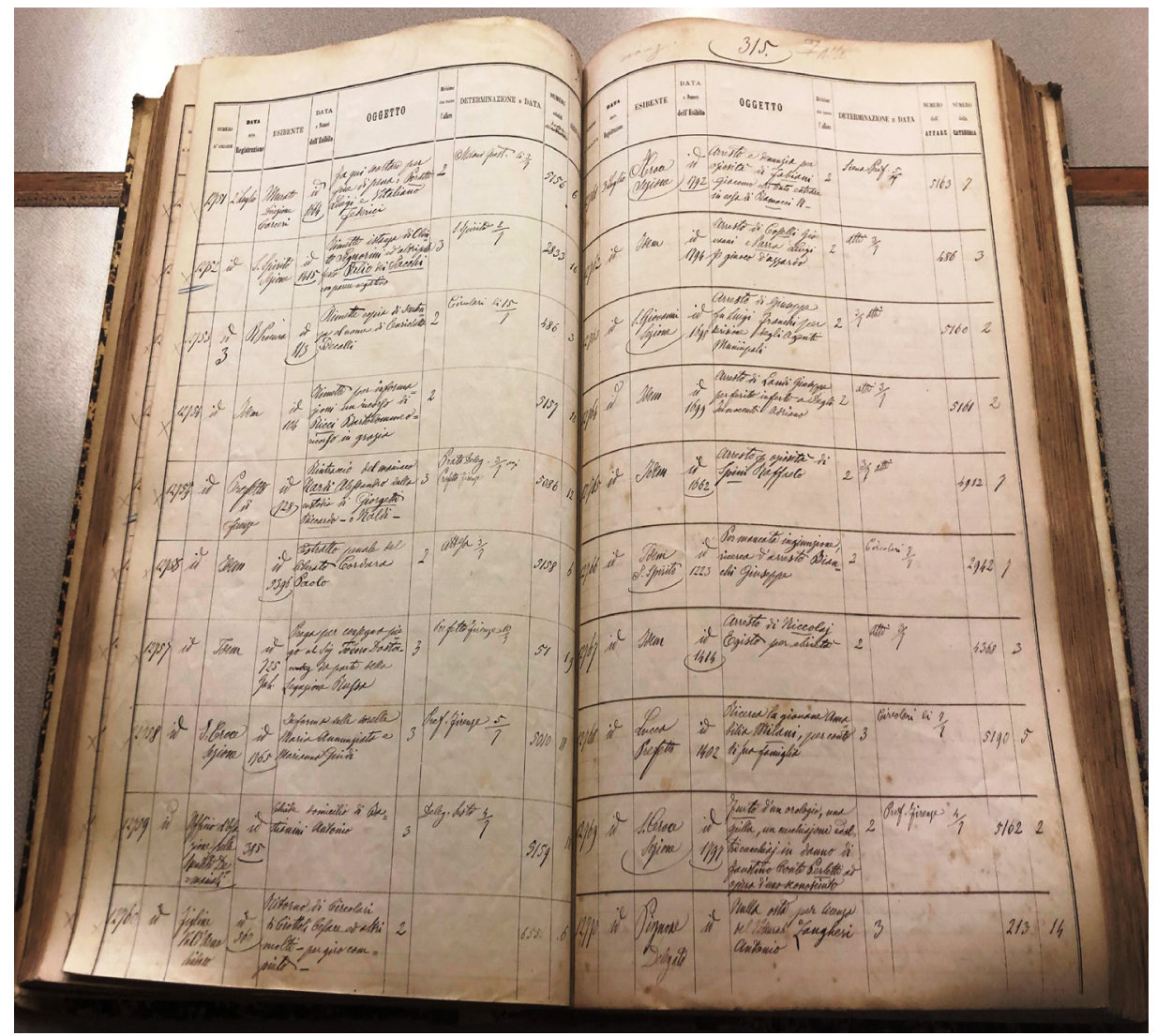

Илл. 4. Общие протоколы квестуры. (Д. 51. Ед. хр. 19)

Эти сведения корреспондируют с документами судебного розыска, обнаруженными в Архиве внешней политики Российской империи (АВПРИ) Министерства иностранных дел Российской Федерации (Москва) и опубликованными В. Н. Захаровым [Захаров, 2012: 276]. Первый документ, описанный в его работе, представляет собой письмо от 24 мая 1871 г., посланное в Императорскую российскую миссию во Флоренцию Департаментом внутренних сношений МИД и содержащее пояснение к исполнительному листу, выданному С.-Петербургским окружным судом по просьбе лужского купца Бурковского. К письму был приложен сам исполнительный лист для вручения его Достоевскому, проживавшему, по сведениям просителя, во Флоренции.

Второй документ, найденный В. Н. Захаровым [Захаров, 2012: 276], написан после получения во Флоренции первого письма, через две недели, это сопроводительное письмо, направленное Императорской российской миссией во Флоренции в Королевскую префектуру этого города с просьбой о вручении данного исполнительного листа адресату. Обнаруженные нами 
в Государственном архиве Флоренции записи о необходимости вручения исполнительного листа Достоевскому являются иллюстрацией последующей истории двух писем, найденных В. Н. Захаровым в АВПРИ МИД РФ.

В фонде «Посольство в Риме» АВПРИ МИД РФ находится и ответ итальянского чиновника с известием о том, что Королевской префектуре установить адрес Достоевского не удалось:

\section{«С 32.492. Сообщения 1871"}

Рим, 19 июля 1871

Уважаемьй господин временный поверенный в делах,

Согласно сообщению, которое я только что получил из Королевской префектуры во Флоренции, я могу известить Вас о том, ито самые тщзательные поиски, предпринятые с целью обнаружения места пребывания в указанном городе российского подданного Феодора Достоевского, не увенчались успехом.

В связи с вышесказанным я должен вернуть Вам исполнительный лист, который был приложен к Вашей записке от прочлого июня 21 дня, и, пользуясь случаем, передать Вам, уважаемый господин временный поверенный в делах, уверения в моем самом глубоком почтении.

Артони

Господину Д. Глинке

Временному поверенному в делах $<\pi .110>»^{4}$.

В 1871 г. Ф. М. Достоевский по-прежнему пребывал в тяжелом материальном положении, был вынужден скрываться от кредиторов и указывал своим корреспондентам адрес для писем «До востребования». Поиски в Историческом архиве коммуны Флоренции (Archivio Storico del Comune di Firenze) и Государственном архиве (Archivio di Stato) показали, что супруги Достоевские не являлись резидентами столицы Итальянского королевства.

Это касается и корреспондента писателя С. П. Колошина, глубоко преданного славянофильским идеям и враждебно настроенного к католицизму. Из-за цензурных запретов Достоевский сумел опубликовать лишь две его статьи ${ }^{5}$. После выхода в отставку с военной службы в 1846 г. Колошин начал печатать юмористические очерки и фельетоны в «Москвитянине», «Пантеоне», «Северной Пчеле» и «Развлечении». В 1853 г. вышел в свет его роман «Светские язвы», содержавший острую сатиру на современное общество. 16 декабря 1861 г. С. П. Колошин начал издавать еженедельный литературный иллюстрированный журнал «Зритель», закрытый 14 сентября 1863 г. Из-за тяжелого материального положения и пошатнувшегося здоровья Колошин уехал в Италию, где служил переводчиком в суде г. Милана и посылал корреспонденции в газеты «Голос» и «Русский Инвалид».

\footnotetext{
1) Запись сделана лиловыми чернилами, иным почерком.

2) Подпись.
} 
Известий о пребывании С. П. Колошина во Флоренции и свидетельств о его смерти не было найдено ни в вышеперечисленных архивах, ни в Архиве гражданских актов коммуны Флоренции (Archivio di Stato Civile Comune di Firenze), о чем дирекцией архива (Direzione Servizi Demografici) был выдан протокол № 152310 от 7 мая 2019 г.

Информация по поводу места смерти С. П. Колошина в справочноэнциклопедической литературе разнится. В «Русском биографическом словаре» место смерти не указано: «Колошинъ, Сергъй Павловичъ, род. 10 января 1825 г. въ Москвъ, ум. 27 ноября 1868 г.» ${ }^{6}$. В «Энциклопедическом словаре» Ф. А. Брокгауза и И. А. Ефрона место смерти также не названо, указан лишь год (заметим, неверный!): «К. † в 1869 г.»7. В известном справочнике «Русские писатели» информация более полная, правильно указано место смерти, но дата приведена ошибочная: «КОЛО́шИН, Калошин Сергей Павлович [10 (22).1.1825, Москва - 9.12.1868, Флоренция]...» ${ }^{8}$. Отметим, что в пределах одной словарной статьи фамилия писателя дается вариативно: то через -o-, то через - $a$-, - отражая встречающиеся в разных изданиях её написания.

В исследовании историка М. Г. Талалая находим следующую информацию: «КАЛОШИН Сергей Павлович, † 15.11.1868, 42 года, майор гусарского полка [Милан, Монументальное кладб., edicola F Ponente, n. 155, колумбарий № 32; МКФ: “общее городское кладб. Милана”. Отпевание записано в книгах церкви Российской миссии в Неаполе, 12.12.1868 (ЦГИА СПб, ф. 19, оп. 123, д. 21, л. 205 об.-206)]» [Талалай: 327]9.

Краткий некролог был опубликован во «Всемирной Иллюстрации»: «Сергъй Калошинъ, бывшій издатель журнала “Зритель” и авторъ статей, помъщавшихся въ разныхъ журналахъ † въ Миланъ 27 ноября 1868 г.» (1869. Т. 1. № 11. 12 марта. С. 163).

Благодаря любезной помощи настоятеля храма архиепископа Георгия Блатинского (Arciprete Gheorghij Blatinskij di Chiesa Ortodossa Russa Firenze), позволившего нам провести поиски в архиве русского православного храма Рождества Христова и Святителя Николая во Флоренции (см.: Илл. 5), нами была обнаружена «метрическая книга, данная изб С. Петербургской Духовной Консисторіи Причту Миссійской Церкви въ Италіи, для записыванія родившихся, бракосочетавшихся и умершихъ за 1868 годъ» (см.: Илл. 6). 


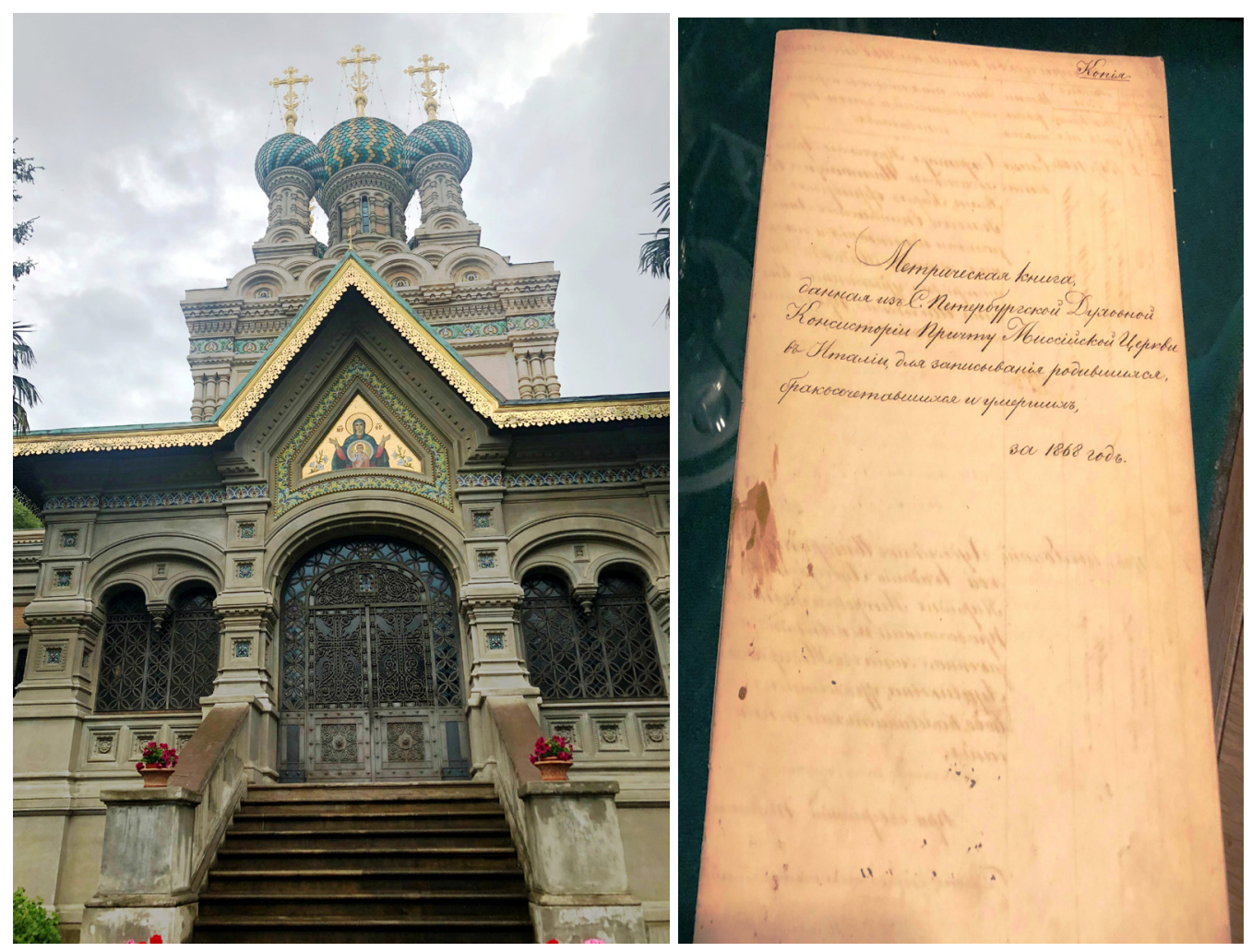

Илл. 5. Православный храм Рождества Христова и Святителя Николая во Флоренции
Илл. 6. Титул метрической книги храма Рождества Христова и Святителя Николая на 1868 г.

Метрические книги, введенные решением Московского церковного собора 1666-1667 гг., представляют собой акты регистрации крещения, венчания и погребения и являются важным коммеморативным и историческим документальным источником. Они дают подлинные свидетельства о судьбе тех или иных лиц, в том числе и умерших за рубежом ${ }^{10}$.

В метрической книге храма была обнаружена запись о причащении, смерти, отпевании и захоронении «майора гусарского полка Сергея Павловича Калошина», который умер «от чахотки» во Флоренции 15 ноября, 16 ноября погребен «на общем городском кладбище в г. Милане, колумбайя № 32»; «таинство Елеосвящения совершил протоиерей Михаил Орлов» (см.: Илл. 7): 


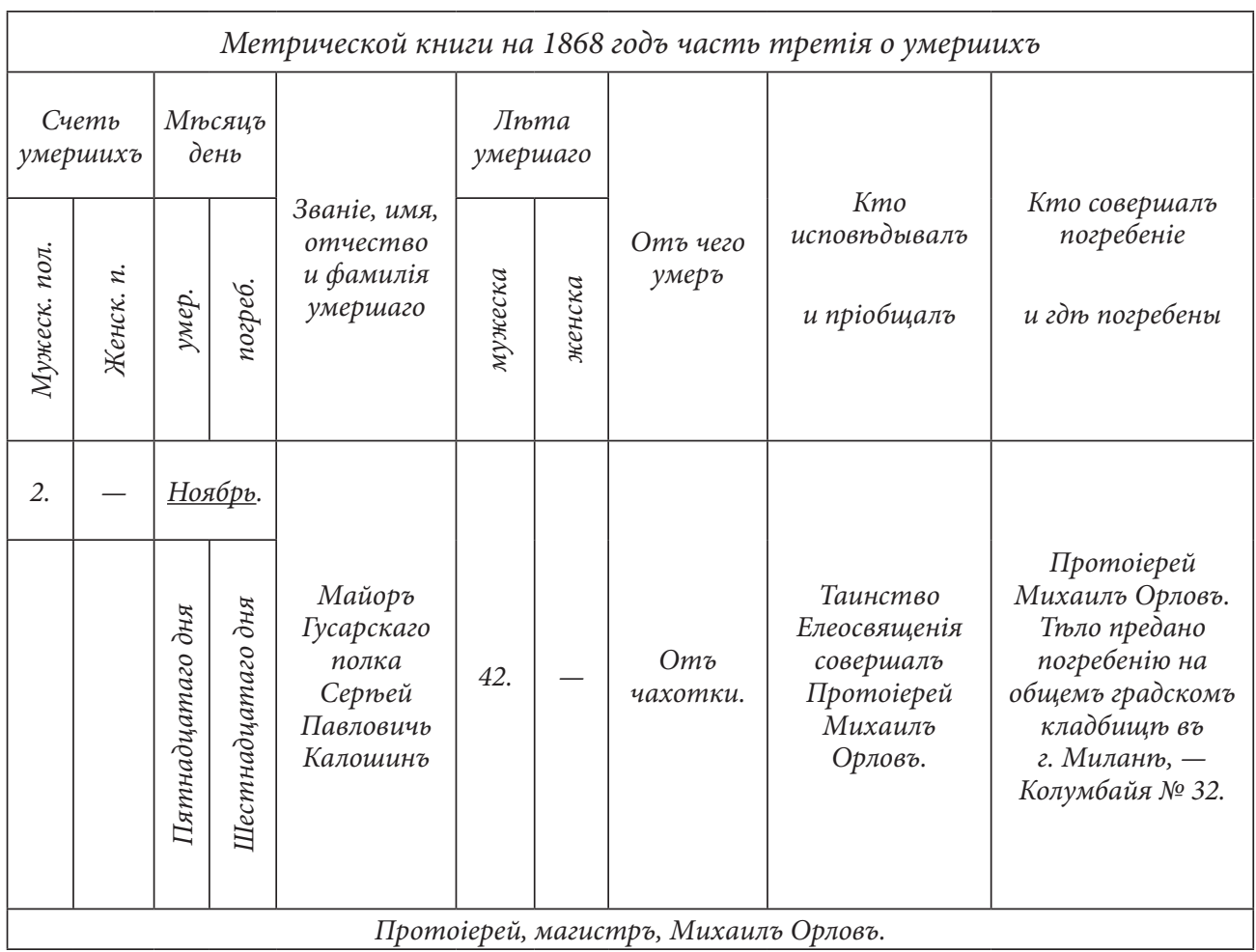

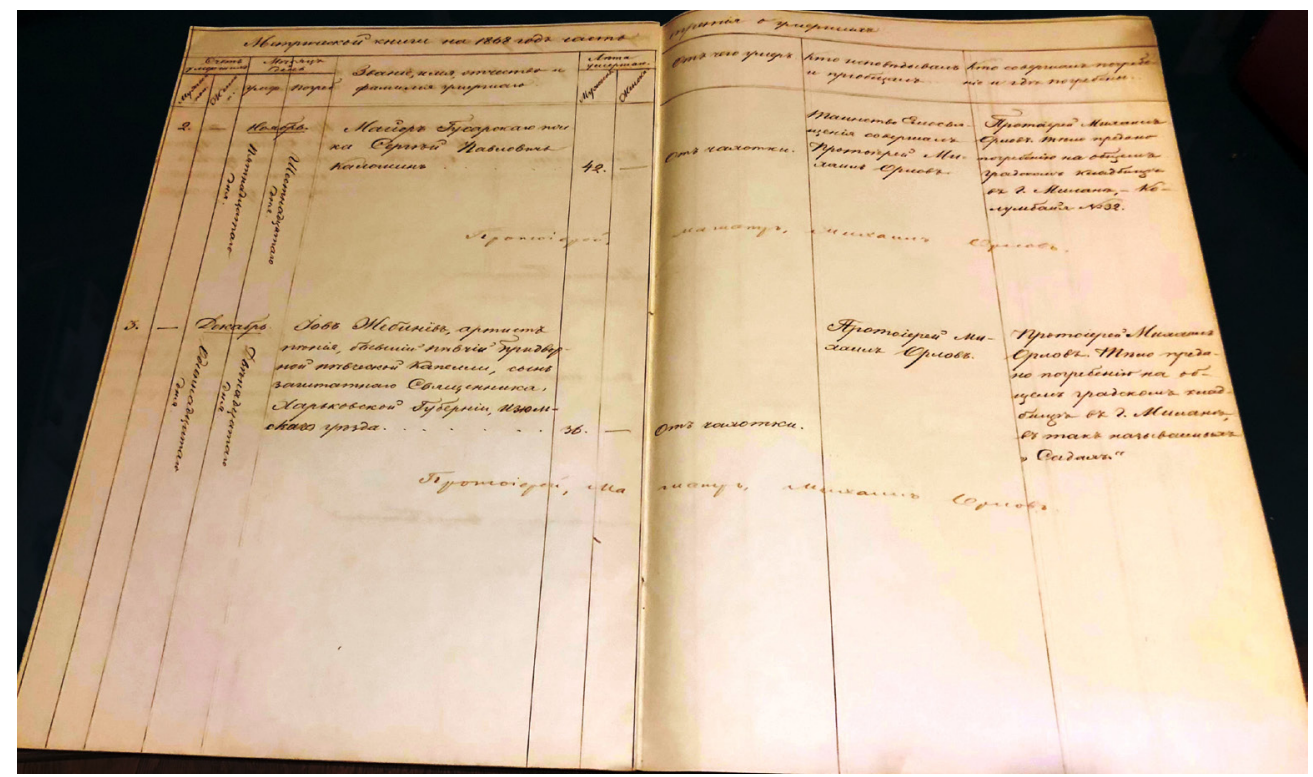

Илл. 7. Запись о погребении С. Колошина в метрической книге храма Рождества Христова и Святителя Николая во Флоренции на 1868 г. 
Отец Георгий пояснил, что протоиерей Михаил Орлов ранее служил в Неаполе, сопровождая походный алтарь Государя Императора Александра. Когда алтарь был перенесен в православный храм Флоренции, он перешел туда на службу. Протоирей Михаил Орлов, совершивший Таинство Елеосвящения и погребения тела С. П. Колошина, почил во Флоренции при храме, не оставив после себя архива. Эти сведения направляют поиски возможных сохранившихся писем Достоевского к журналисту С. П. Колошину в новое русло: есть вероятность, что, умирая одиноким во Флоренции, Колошин мог оставить свой архив душеприказчику.

\section{ПРИМЕЧАНИЯ}

* Исследование выполнено при финансовой поддержке Российского фонда фундаментальных исследований (РФФИ) в рамках научного проекта № 18-012-90034 Достоевский («Достоевский и Италия»).

** Авторы выражают глубокую благодарность сотруднику Государственного архива Флоренции г. Андреа Тантури, оказавшему неоценимую помощь в работе с документами архива, касающимися судебного розыска Достоевского.

1 Достоевский Ф. М. Полн. собр. соч.: в 30 т. Л.: Наука, 1985. Т. 28. . С. 334. Далее ссылки на это издание приводятся в тексте статьи с сокращением Д30 и с указанием тома, книги (нижний индекс) и страницы в круглых скобках.

2 О значении Флоренции для Достоевского см. работы: [Алоэ, 2000], [Алоэ, 2019], [Дергачева], [Кара-Мурза], [Литвин], [Прожогин], [Супино], [Талалай], [Тонини], [Mascagni], [Strelsky], [Supino].

3 Все фотографии в статье - И. В. Дергачевой.

4 Перевод выполнен И. В. Дергачевой. В оригинале: «32. 492. Trasmissions 1871

Rome, ce 19 juillet 1871.

Monsieur le Charge d'Affaires,

D'apre's une communication que je viens de recéevoir de la Prèfecture Royale à Florence, je suis en mesure de Vous faire connaitre, que les recherches les plus minutieuses faites dans le but de dècouvrir le domicile dans la dite Ville du sujet Russe Thèodore Dostoessky ont è infructueuses.

Je dois par suite Vous restituer le pli qui ètait annexè á Votre Note du 21 Juin dernier, et je saisis cette occasion pour Vous rèitèrer, Monsieur le Chargè d'Affaires, les assurances de ma considèration trés distinguèe.

A Monsieur

Artony [nodnucb]

M. $[\dot{i}]$ Glinka

Chargè d'Affaires de Russie».

5 [Колошин С. К.] Рим, папа и Антонели. Политический очерк (Подпись: С. К.) // Эпоха. 1864. Март. С. 98-119; [Колошин С. К.] Иезуиты и их уложение (Подпись: С. К-нъ) // Эпоха. 1864. Июнь. С. 257-263 [Нечаева: 255-256, 269], [Захаров, 2013].

6 Русскій біографическій словарь / изд. подъ набл. предсъд. Императ. Рус. Ист. Общества А. А. Половцова. СПб.: Типографія Главнаго Управленія Удъловъ, 1903. Т. 9: Кнаппе - Кюхельбекеръ. С. 79 [Электронный ресурс]. URL: https://dlib.rsl.ru/viewer/01002921660\#?page $=81$ 
7 Энциклопедический словарь Ф. А. Брокгауза и И. А. Ефрона. СПб.: Брокгауз - Ефрон, 1895. T. XVa: Коала - Конкордия. С. 761-762 [Электронный ресурс]. URL: https://dic. academic.ru/dic.nsf/brokgauz_efron/54015

8 Русские писатели 1800-1917: биографический словарь. М.: Большая Российская энциклопедия, Фианит, 1994. Т. 3: К - М. С. 28.

9 Консисторские экземпляры всех сохранившихся метрических книг православных церквей при российских миссиях за границей хранятся в 123 описи этого фонда и архива. Отметим, что номер дела тут указан ошибочный. Правильно: ЦГИА СПб. Ф. 19. Оп. 123. Д. 24 (см. на портале «Архивы Санкт-Петербурга»: https://spbarchives.ru/infres/-/ archive/cgia/19/123/24).

10 Указ Петра I в 1702 г. «О подаче в Патриарший духовный приказ приходским священникам недельных ведомостей о родившихся и умерших» закрепил эту практику, а с 1722 г. в «Прибавлениях к Духовному регламенту» говорится о необходимости ведения метрических книг в Российской империи. В Указе Синода от 1724 г. введены формы метрических книг. Окончательно формуляр был утвержден в 1838 г.: книги имели три части, содержащие сведения о рождении, браке и смерти. Третья часть указывала имя, фамилию, место жительства, возраст умершего, дату и причину смерти, место захоронения. Бланки книг выдавались приходским священникам и велись ими в двух экземплярах: один направлялся в архив консистории, второй оставался в приходе церкви (как раз в приходском экземпляре метрической книги, сохранившемся в архиве местного храма, находится приводимая ниже впервые фотокопия записи об отпевании С. Колошина; второй, консисторский, экземпляр этой книги находится в Центральном государственном историческом архиве Санкт-Петербурга (ЦГИА СПб) - ссылка на него дается в указанной выше работе М. Г. Талалая.) Метрические книги регистрировали церковные обряды, а не сам факт смерти, поэтому умершие, вынужденно похороненные без участия духовенства, в них не попадали.

\section{СПИСОК ЛИТЕРАТУРЫ}

1. Алоэ С. Первые этапы знакомства с Ф. М. Достоевским в Италии // Достоевский и мировая культура. Альманах № 15. - СПб.: Серебряный век, 2000. - С. 139-153.

2. Алоэ С. Италия в биографии Ф. М. Достоевского: несколько вводных заметок по поводу архивных находок Валентины Супино // Неизвестный Достоевский. — 2019. № 1. - C. 3-9 [Электронный ресурс]. — URL: http://unknown-dostoevsky.ru/files/ redaktor_pdf/1554980371.pdf(15.05.2019). DOI: 10.15393/j10.art.2019.3801

3. Дергачева И. В. «А мне Россия нужна...»: мысли Ф. М. Достоевского о Родине // Язык и текст. - 2018. - Т. 5. - № 4. - С. 9-13 [Электронный ресурс]. — URL: http:// psyjournals.ru/langpsy/2018/n4/Dergacheva.shtml (15.05.2019). DOI:10.17759/langt.2018050402

4. Дергачева И. В. Образы Италии в эпистолярном наследии Достоевского // Язык и текст. - 2019. - Т. 6. - № 1. - C. 38-44 [Электронный ресурс]. — URL: http:// psyjournals.ru/langpsy/2019/n1/Dergacheva.shtml (15.05.2019). DOI:10.17759/langt.2019060106

5. Достоевская А. Г. Воспоминания. 1846-1917 / вступ. ст., подгот. текста, примеч. И. С. Андриановой и Б. Н. Тихомирова. - М.: Бослен, 2015. - 768 с.

6. Достоевский - абонент флорентийской читальни // Достоевский. Материалы и исследования. - Л.: Наука, 1980. - Т. 4. - С. 174-175. 
7. Захаров В. Н. Неопубликованный автограф Достоевского: Ф. М. Достоевский и С. П. Колошин // Ученые записки Петрозаводского государственного университета. - Петрозаводск: ПетрГУ, 2013. - № 7 (136). - Т. 2. - С. 58-61 [Электронный ресурс]. — URL: http://uchzap.petrsu.ru/files/n136-2.pdf (15.05.2019).

8. Захаров В. Н. Судебный розыск Достоевского летом 1871 г. // Достоевский и мировая культура. Альманах № 29. - СПб., 2012. - С. 276-277.

9. Кара-Мурза А. А. Знаменитые русские о Флоренции. - М.: Изд-во Ольги Морозовой, 2016. - 639 c.

10. Кудрявцев О. Ф. «Умри, Флоренция, Иуда» // Итальянское Возрождение в восприятии русской культуры. - М., 2004. - № 5. - С. 214-222.

11. Кудрявцев О. Ф. Флорентийская Платоновская Академия (Очерк истории духовной жизни ренессансной Италии). — 2-е изд., испр. и доп. - М.: ЛУМ, 2018. — 544 с.

12. Литвин Е. А. Достоевский и послевоенное итальянское общество: «Партнер» Бертолуччи // Язык и текст. - 2018. - Т. 5. - № 4. - С. 25-31 [Электронный ресурс]. URL: http://psyjournals.ru/langpsy/2018/n4/Litvin.shtml (15.05.2019). DOI:10.17759/ langt.2018050404

13. Нечаева В. С. Журнал М. М. и Ф. М. Достоевских «Эпоха» (1864-1865). — М.: Наука, 1975. $-303 \mathrm{c}$.

14. Прожогин Н. П. Достоевский во Флоренции // Иностранная литература. — 1981. — № 8. - С. 237-244.

15. Прожогин Н. П. Достоевский во Флоренции в 1868-1869 гг. // Достоевский. Материалы и исследования. - Л.: Наука, 1983. - Т. 5. - С. 204-208.

16. Супино В. Флорентийские адреса Достоевского // Неизвестный Достоевский. — 2019. № 1. - C. 10-27 [Электронный pecypc]. — URL: http://unknown-dostoevsky.ru/files/ redaktor_pdf/1554980289.pdf (15.05.2019). DOI: 10.15393/j10.art.2019.3841.

17. Талалай М. Г. Российский некрополь в Италии / под ред. А. А. Шумкова. - М.: Старая Басманная, 2014. - 908 + LXXX с. (Сер. «Российский некрополь»; вып. 21) [Электронный ресурс]. - URL: https://imwerden.de/pdf/talalay_rossijsky_nekropol_v_italii_2014. pdf (15.05.2019).

18. Тонини Лючия. Первые читатели Достоевского в реестрах кабинета Вессе во Флоренции // Современные проблемы изучения поэтики и биографии Достоевского: рецепция, вариации, интерпретация / под ред. В. Н. Захарова, К. А. Степаняна, Б. Н. Тихомирова. - СПб.: Дмитрий Буланин, 2016. - С. 329-342. (Dostoevsky Monograhps; vol. 5).

19. Mascagni R. Dostoevskij a Firenze // Reality. — 2017. — № 86. — Pp. 54-55.

20. Strelsky K. Dostoevsky in Florence // The Russian Review. - Vol. 23. - No. 2 (Apr., 1964). Pp. 149-163.

21. Supino V. I soggiorni di Dostoevskij in Europa e la loro influenza sulla sua opera: 2a edizione. Firenze: LoGisma, 2017. - 134 p. 
Giuseppe Astuto

(Catania, Italy)

astuto@unict.it

Irina V. Dergacheva

(Moscow, Russian Federation)

krugh@yandex.ru

\section{In the Footsteps of Dostoevsky in Florence}

Acknowledgments. The reported study was funded by RFBR, project number 18-01290034 Dostoevsky.

Abstract. The article represents the results of an archival research conducted in spring of 2019 with the purpose to find the traces of F. M. Dostoevsky during his visit to Florence. New documents supplementing the history of an execution writ of a merchant from luzhsky district Burkovsky who did not manage to hand it over the writer because of the departure of the latter, were found and analyzed. Two documents were found In the Florence State Archive, composed by the prefect's order in response to the temporary attorney Glinka's request for search of the writer for the purpose to give him the above mentioned document. In addition, the article for the first time provides a photocopy of the record from the parish register of 1868, held in the Orthodox Cathedral of the Nativity of Jesus Christ and St. Nicholas, about the burial service, death and funeral of S. P. Koloshin, a newsman and correspondent of Dostoevsky, whose archive containing Dostoevsky's letters has not been found yet.

Keywords: Dostoevsky, Florence, S. P. Koloshin, Orthodox Cathedral of the Nativity of Jesus Christ and St. Nicholas, parish register, judicial search, the Florence State Archive, the Historical archive of Florence

About the authors: Astuto Guiseppe - PhD, Professor of History of political institutes at the faculty of political arts, University of Catania (Via Vittorio Emanuele II, 49, Catania CT, 95131, Italy); Dergacheva Irina V. - Doctor of Philology, Professor, Head of the Department of linguistics of Faculty of State Cultural Politics, Moscow State University of Culture (ul. Bibliotechnaya, 7, Khimki, Moskovskaya obl., 141406, Russian Federation)

Received: May 20, 2019

Date of publication: June 30, 2019

For citation: Astuto G., Dergacheva I. V. In the Footsteps of Dostoevsky in Florence. In: Neizvestnyy Dostoevskiy [The Unknown Dostoevsky], no. 2, 2019, pp. 130-148. DOI: 10.15393/j10. art.2019.4022 (In Russ.)

\section{REFERENCES}

1. Aloe S. The First Stages of Acquaintance with Dostoevsky in Italy. In: Dostoevskiy i mirovaya kul'tura. Al'manakh № 15 [Dostoevsky and World Culture. Almanac No. 15]. St. Petersburg, Serebryanyy vek Publ., 2000, pp. 139-153. (In Russ.)

2. Aloe S. Italy in the Biography of F. M. Dostoevsky: Several Introductory Notes About the Archival Finds of Valentina Supino. In: Neizvestnyy Dostoevskiy [The Unknown Dostoevsky], 2019, no. 1, pp. 3-9. Available at: http://unknown-dostoevsky.ru/files/redaktor_pdf/1554980371. pdf (accessed on May 15, 2019). DOI: 10.15393/j10.art.2019.3801 (In Russ.) 
3. Dergacheva I. V. “And I Need Russia...”: Thoughts F. M. Dostoevsky About the Motherland. In: Yazyk i tekst [Language and Text], 2018, vol. 5, no. 4, pp. 9-13. Available at: http://psyjournals.ru/langpsy/2018/n4/Dergacheva.shtml (accessed on May 15, 2019). DOI:10.17759/ langt.2018050402 (In Russ.)

4. Dergacheva I. V. Images of Italy in Dostoevsky’s Epistolary Heritage. In: Yazyk i tekst [Language and Text], 2019, vol. 6, no. 1, pp. 38-44. Available at: http://psyjournals.ru/langpsy/2019/n1/ Dergacheva.shtml (accessed on May 15, 2019). DOI:10.17759/langt.2019060106 (In Russ.)

5. Dostoevskaya A. G. Vospominaniya. 1846-1917 [Memoirs. 1846-1917]. Moscow, Boslen Publ, 2015. 768 p. (In Russ.)

6. Dostoevsky as a Subscriber of the Florentine Community Center. In: Dostoevskiy. Materialy $i$ issledovaniya [Dostoevsky. Materials and Researches]. Leningrad, Nauka Publ., 1980, pp. 174-175. (In Russ.)

7. Zakharov V. N. Unpublished Autograph of Dostoevsky: Fedor Dostoevsky and Sergey Koloshin. In: Uchenye zapiski Petrozavodskogo gosudarstvennogo universiteta [Proceedings of Petrozavodsk State University]. Petrozavodsk, Petrozavodsk State University Publ., 2013, no. 7 (136), vol. 2, pp. 58-61. Available at: http://uchzap.petrsu.ru/files/n136-2.pdf (accessed on May 15, 2019). (In Russ.)

8. Zakharov V. N. Judicial Search of Dostoevsky in the Summer of 1871. In: Dostoevskiy i mirovaya kul'tura. Al'manakh № 15 [Dostoevsky and World Culture. Almanac No. 29]. St. Petersburg, 2012, pp. 276-277. (In Russ.)

9. Kara-Murza A. A. Znamenitye russkie o Florentsii [Famous Russians About Florence]. Moscow, Izdatel'stvo Ol'gi Morozovoy Publ., 2016. 639 p. (In Russ.)

10. Kudryavtsev O. F. "Die, Florence, Judas”. In: Ital'yanskoe Vozrozhdenie v vospriyatii russkoy kul'tury [Italian Renaissance as Percepted in Russian Culture]. Moscow, 2004, no. 5, pp. 214222. (In Russ.)

11. Kudryavtsev O. F. Florentiyskaya Platonovskaya Akademiya (Ocherki istorii dukhovnoy zhizni renessansnoy Italii) [The Platonic Academy in Florence (Essay on the History of Spiritual Life of Renaissant Italy)]. Moscow, LUM Publ., 2018. 544 p. (In Russ.)

12. Litvin E. A. Dostoevsky and the Post-War Italian Society: Bertolucci’s "Partner”. In: Yazyk i tekst [Language and Text], 2018, vol. 5, no. 4, pp. 25-31. Available at: http://psyjournals.ru/ langpsy/2018/n4/Litvin.shtml (accessed on May 15, 2019). DOI:10.17759/langt.2018050404 (In Russ.)

13. Nechaeva V. S. Zhurnal M. M. i F. M. Dostoevskikh «Epokha» (1864-1865) [The Journal of Mikhail and Fedor Dostoevsky "Epokha" (1864-1865)]. Moscow, Nauka Publ., 1975. 303 p. (In Russ.)

14. Prozhogin N. P. Dostoevsky in Florence. In: Inostrannaya literatura, 1981, no. 8, pp. 237-244. (In Russ.)

15. Prozhogin N. P. Dostoevsky in Florence in 1868-1869. In: Dostoevskiy. Materialy i issledovaniya [Dostoevsky. Materials and Researches]. Leningrad, Nauka Publ., 1983, vol. 5, pp. 204208. (In Russ.)

16. Supino V. Florentine Addresses of Dostoevsky. In: Neizvestnyy Dostoevskiy [The Unknown Dostoevsky], 2019, no. 1, pp. 10-27. Available at: http://unknown-dostoevsky.ru/files/redaktor_ pdf/1554980289.pdf (accessed on May 15, 2019). DOI: 10.15393/j10.art.2019.3841 (In Russ.)

17. Talalay M. G. Rossiyskiy nekropol'v Italii [The Russian Necropolis in Italy]. Moscow, Staraya Basmannaya Publ., 2014. 908 p. (Ser. “The Russian necropolis”; vol. 21). Available at: https:// 
imwerden.de/pdf/talalay_rossijsky_nekropol_v_italii_2014.pdf (accessed on May 15, 2019). (In Russ.)

18. Tonini Lyuchiya. The First Readers of Dostoevsky in the Registers of the Office of Vieusseux in Florence. In: Sovremennye problemy izucheniya poetiki i biografii Dostoevskogo: Retseptsiya, variatsii, interpretatsiya [Modern Problems of Studying Dostoevsky's Poetics and Biography: Reception, Variations, Interpretation]. St. Petersburg, Dmitriy Bulanin Publ., 2016, pp. 329-342. (Dostoevsky Monographs; vol. 5). (In Russ.)

19. Mascagni R. Dostoevskij a Firenze [Dostoevsky in Florence]. In: Reality, 2017, no. 86, pp. 54-55. (In Italian)

20. Strelsky K. Dostoevsky in Florence. In: The Russian Review, vol. 23, no. 2 (Apr., 1964), pp. 149-163. (In English)

21. Supino V. I soggiorni di Dostoevskij in Europa e la loro influenza sulla sua opera [Dostoevsky's Stay in Europe and Its Influence on His Work]. Firenze, LoGisma Publ., 2017. 134 p. (In Italian) 